\title{
Poverty in the first-century Galilee
}

\begin{tabular}{|c|c|}
\hline \multicolumn{2}{|c|}{$\begin{array}{l}\text { Author: } \\
\text { Sakari Häkkinen }{ }^{1}\end{array}$} \\
\hline \multicolumn{2}{|c|}{$\begin{array}{l}\text { Testament Studies, Faculty of } \\
\text { Theology, University of } \\
\text { Pretoria, South Africa }\end{array}$} \\
\hline \multicolumn{2}{|c|}{$\begin{array}{l}\text { Project leader: A.G. van Aarde } \\
\text { Project number: } 2334682\end{array}$} \\
\hline \multicolumn{2}{|c|}{$\begin{array}{l}\text { Dr Sakari Häkkinen is } \\
\text { participating as a research } \\
\text { fellow in the project 'Biblical } \\
\text { Theology and Hermeneutics', } \\
\text { directed by Prof. Dr Andries G. } \\
\text { van Aarde, Post Retirement } \\
\text { Professor, Department of New } \\
\text { Testament Studies, Faculty of } \\
\text { Theology, University of } \\
\text { Pretoria }\end{array}$} \\
\hline \multicolumn{2}{|c|}{$\begin{array}{l}\text { Corresponding author: } \\
\text { Sakari Häkkinen, } \\
\text { sakari.hakkinen@evl.fi }\end{array}$} \\
\hline \multicolumn{2}{|c|}{$\begin{array}{l}\text { Received: } 04 \text { Mar. } 2016 \\
\text { Accepted: } 02 \text { Apr. } 2016 \\
\text { Published: } 22 \text { Sept. } 2016\end{array}$} \\
\hline \multicolumn{2}{|c|}{$\begin{array}{l}\text { How to cite this article: } \\
\text { Häkkinen, S., 2016, 'Poverty } \\
\text { in the first-century Galilee', } \\
\text { HTS Teologiese Studies/HTS } \\
\text { Theological Studies 72(4), } \\
\text { a3398. http://dx.doi. } \\
\text { org/10.4102/hts.v72i4.3398 }\end{array}$} \\
\hline \multicolumn{2}{|c|}{$\begin{array}{l}\text { Copyright: } \\
\text { (c) 2016. The Authors. } \\
\text { Licensee: AOSIS. This } \\
\text { is licensed under the } \\
\text { Creative Commons } \\
\text { Attribution License. }\end{array}$} \\
\hline \multicolumn{2}{|l|}{ Read online: } \\
\hline 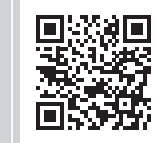 & $\begin{array}{l}\text { Scan this QR } \\
\text { code with your } \\
\text { smart phone or } \\
\text { mobile device } \\
\text { to read online. }\end{array}$ \\
\hline
\end{tabular}

In the Ancient world poverty was a visible and common phenomenon. According to estimations 9 out of 10 persons lived close to the subsistence level or below it. There was no middle class. The state did not show much concern for the poor. Inequality and disability to improve one's social status were based on honour and shame, culture and religion.

In order to understand the activity of Jesus and the early Jesus movement in Galilee, it is essential to know the social and economic context where he and his followers came. The principal literary source in first-century Galilee is Josephus, who provides a very incomplete glimpse of the political and economic character of the Galilee and his account is both tendentious and selfserving. There is no consensus among the scholars on the conditions of ordinary people in Galilee at the time of Jesus and the early Jesus movement. The evidence can be interpreted either so that first-century Galilee was peaceful and people had somewhat better times economically because of the large building projects, or just the opposite - the building projects demanded a lot more taxes and forced labour and made life even more difficult. In this article it is argued that the latter conditions explain better the birth and rapid increase of the early Jesus movement in Galilee.

Inequality was typical for all the societies in the Ancient world. M.I. Finley (1999) writes:

The obvious difficulty with the city-state as a community, with its stress on mutual sharing of both burdens and benefits, was the hard fact that its members were unequal. The most troublesome inequality was not between town and country, not between classes, but simply between rich and poor. (p. 152)

The social and economic policy of the Roman Empire could well be summarised in a phrase: 'the Roman system of inequality' (Garnsey \& Saller 1987:125). ${ }^{1}$ Governing the entire Mediterranean world, Rome maintained its domination through judicial institutions developing legislation concerning property ownership and labour control - and through the use of brutal force. The whole system was based heavily on the inequality of people, which was thought to be either natural or at least inevitable, in order to secure peace and stability in the society.

For the Roman State, the provinces were a main source of revenue through taxes. A small number of Romans made large fortunes as provincial governors, tax collectors and moneylenders in the provinces, in the imperial service under the emperors. There were rich Romans who acquired extensive domains in the provinces, which they normally held as absentee landlords (Finley 1999:158). Most of the population of the empire lived either in rural areas or small towns. Only $10 \%-15 \%$ of the population lived in cities that had more than 10000 inhabitants. This means that some $80 \%-90 \%$ got their living from agriculture and that any large-scale commercial or manufacturing activity was rare. There was no middle class at all. The majority of people in an agrarian society like the Roman Empire were peasants, living in villages that surrounded a city. The ancient city was largely parasitic on its surrounding villages. Cities extracted agricultural surpluses through taxes and rents. The benefits they supplied were cultic services and administration (Kloppenborg Verbin 2000:234). ${ }^{2}$

\section{According to Bruce J. Malina, the first-century Mediterranean world is:}

a nearly perfect example of what anthropologists call classic peasant society: a set of villages socially bound up with administrative preindustrial cities. ... The term 'peasant' in the phrase 'peasant society' refers to persons, regardless of their occupation, who have been enculturated in and continue to be members of peasant society.

\section{Malina speaks of:}

a 'peasant mentality' of peasant society typical of beggar and king, of smallholder and large landowner, of prophet and scribe. This 'peasant mentality' is a societal characteristic, not a status or occupational feature. (Malina 2001:81)

1.Inequality was typical for all the societies in the Ancient world.

2.A more comprehensive description of the symbiotic relations between an ancient city and villages surrounding it is offered by Malina (2001:85-88). 
Douglas E. Oakman (2008) summarises some definitions of a peasant:

A peasantry is a rural population, usually including those not directly engaged in tilling the soil, who are compelled to give up their agricultural (or other economic) surplus to a separate group of power holders and who usually have certain cultural characteristics setting them apart from outsiders. Generally speaking, peasants have very little control over their political and economic situation. In Mediterranean antiquity the overlords of the peasants tended to be city dwellers, and a culture-chasm divided the literate elite from the unlettered villager. (p. 167)

In agrarian society wealth was based on the ownership of land. Most land was controlled by a small number of wealthy, elite families. The landowners rented the land for tenant farmers, who - together with their families and possibly slaves - actually worked the land. The wealth and status of the elite families ensured their influence in politics, so that they were able to control both local and regional governance and also profit from taxation. The same families quite often controlled public religion as well (Friesen 2008:19).

These elite families, the 'urban elite' (Rohrbaugh 1993:383), consisted of the rulers and the governing class. According to Gerhard Lenski, agrarian societies ${ }^{3}$ consisted usually of following classes, the four first-mentioned forming the privileged elements of an agrarian society (Lenski 1984: 189-296):

- the rulers and the governing class, consisting rarely more than $2 \%$ of the population

- the retainer class (perhaps some 5\%), consisting of a small army of officials, professional soldiers, household servants ${ }^{4}$ and personal retainers

- the merchant class, that seems to have evolved slowly from the ranks of peasants, many of whom remained poor, but the leading members might have been wealthier than the lesser members of the governing class

- the priestly class, whose size and prosperity varies a lot among the agrarian societies

- the peasant class, constituting the substantial majority of the population, and having the biggest burden of supporting the state and the privileged classes

- the artisan class $(3 \%-7 \%)$, that was economically quite close to the peasant class, but often with lower income

- unclean and degraded classes who occupied a position in society which was clearly inferior to that of the masses of common people

- the expendables, at the bottom of the class system, consisting of petty criminals and outlaws, beggars, underemployed itinerant workers and people who lived solely by their wits or by charity.

According to Lenski (1984:210), typical to agrarian societies is the fact of marked social inequality. In these societies the

\footnotetext{
3.Lenski first discusses the justification for treating agrarian societies as a generic type. When viewed from the perspective of all human societies, the similaries clearly outweigh the differences, but internal variations and important subtypes among the classification system exist (1984:191).
}

4.'Household servants' is used by Lenski for slaves. institutions of government are the primary source of social inequality

The rulers were the heads of the empire and the centralised states, whereas the governing class formed the local administration. Together these privileged elite, very few in numbers, drew its wealth from the products of peasants and herders, craftsmen and traders. These products funded a lavish lifestyle for the ruling class and its priests, scribes and bureaucrats, as well as palaces, temples, fortifications, monuments and a forceful army. Members of the imperial ruling class enjoyed a comfortable and privileged standard of living without engaging in any productive labour on behalf of society and with no obligation to those they ruled other than to assure that they were able to produce sufficient wealth to sustain the rulers in their privilege (Gottwald 2008:10-11). ${ }^{5}$ It has been estimated that at least half of the annual production went to the urban elite, no less than a quarter to the ruling class and approximately the same to the local governing class (Lenski 1984:220). However, as the land and its products was the main resource for wealth in agrarian society, there were continuous tensions between the rulers and the governing class, sometimes even struggles on the distribution of the income (Lenski 1984:241). Religion was needed for authorising this oppression system, therefore also the priests belonged usually to the few privileged, but of course there might have been great regional differences concerning the social strata of the priestly class in the mighty empire. However, the priestly class tended to function as the preserver of the ancient redistributive ethic of primitive societies (Lenski 1984:266).

In the Roman Empire only the governing class and some of its retainers were literate. Most men and some women of the urban elite aristocrats could read, although they often had educated slaves to read to them and write letters and other documents for them. But literacy was not used in most social and economic interaction, certainly not among the ordinary people. The culture was predominantly oral (Horsley 2008:28-29, 89-92; Oakman 2008:300-303).

The state granted 'use ownership' of the land to the peasants, but it claimed entitlement to tax the villages, first in the form of payments in kind and second in the form of conscription to public labour or military service. Often the tax quota was laid on an entire village and the local officers had to raise the demanded amount. Internal corruption occurred when tax gatherers and village headmen took possession of goods and produce over and above the quota assigned them by the central government. The taxation was double: Rome demanded taxes from its provinces in order to sustain the government and the army and to build roads which were essential to the empire. The local vassal kings took their share in order to sustain their own privileged life and to build palaces, new cities and monuments dedicated to the Caesar.

5.Even though Gottwald describes ancient empires in general, and has, especially, Egypt, Assyria and Babylon in mind, the description fits remarkably well for the
Roman Empire as well. A good description of the living conditions of the wealthy elite is given by Malina (2001:85-88) 
The taxes were extracted at the time of the harvest and transported to the city. In times of poor harvests this meant that the farmer was left to suffer or even starve (Garnsey \& Saller 1987:97). Besides direct taxation, villagers were subject to a variety of other impositions, including forced labour and the requisitioning of carts and animals for transport. This further impinged on the viability of economically marginal farming operations. In addition to imperial levies, cities derived revenues from capitation, rents, tolls, salt taxes and sales taxes (Kloppenborg Verbin 2000:235).

Many peasants, already living at the margin of subsistence, were further impoverished and driven into debt by harsh annual exactions. They had to take out loans at staggering amounts of interest offered by money-lending merchants and absentee landlords. The debtors were obligated to pay back the value of the loan from the forthcoming harvest, plus the value-added interest. Repayment of loans depended on good harvests, which often failed because of drought, floods, disease and the ravages of warfare. Foreclosure on debts could force peasants into debt servitude, one-sided client relationship with their patron creditors, or outright loss of land that turned them into day labourers or beggars (Gottwald 2008:10-11). ${ }^{6}$

Poverty was widespread both in rural and urban areas. According to Friesen, biblical scholars tend to underestimate the overwhelming poverty that characterised the Roman Empire. Therefore, he developed a poverty scale that, more accurately than Lenski's quite general one, provides seven categories for describing economic resources especially in the ancient city of Rome (Friesen 2008:19-20):

1. imperial elites: consisting of $0.04 \%$ of the population: imperial dynasty, Roman senatorial families, a few retainers, local royalty and a few feedpersons

2. regional or provincial elites (1\%): equestrian families, provincial officials, some retainers, some decurial families, some freedpersons, some retired military officers

3. municipal elites $(1.76 \%)$ : most decurial families, wealthy men and women who do not hold office, some freedpersons, some retainers, some veterans, some merchants

4. moderate surplus resources ( $7 \%$ estimated): some merchants, some traders, some freedpersons, some artisans (especially those who employ others) and military veterans

5. stable near subsistence level with reasonable hope of remaining above the minimum lever to sustain life $(22 \%$ estimated): many merchants and traders, regular wage earners, artisans, large shop owners, freed persons and some farm families

6. at subsistence level and often below minimum level to sustain life (40\%): small farm families, labourers (skilled and unskilled), artisans (especially those employed by others), wage earners, most merchants and traders, small shop or tavern owners

6.On the problem of debt see Oakman (2008:11-32). Oakman also describes the distinctive situations concerning debt between Judaea and Galilee (p. 16) and the harshness of Roman laws concerning debt (p. 24).
7. below subsistence level (28\%): some farm families, unattached widows, orphans, beggars, disabled, unskilled day labourers and prisoners.

The percentages in Friesen's scale are based on data from urban centres of 10000 inhabitants or more. In rural areas poverty was even worse: although super-wealthy elites (categories 1-3) made up about 3\% of an urban population, they were only about $1 \%$ of the total imperial population (Friesen 2008:19; Stegemann \& Stegemann 1999:81-85). ${ }^{\text {? }}$

So, according to Friesen, the wealthy elites formed only $1 \%-3 \%$ of the whole population of the empire. Friesen does not, for some reason, include the priestly class in his table at all, but I assume that the priestly class would have belonged to all three groups that formed the elite. In some areas, like Jerusalem, though, the number of the priests (some 20000 together with the lower clergy, the Levites) was so high that the majority of them belonged most probably to categories 4 and $5 .^{8}$ Also, Friesen does not explicitly mention the scribes, who served the regional administration, but according to his stratification they must have belonged either to category 2 as regional or provincial elites, or to category 3 belonging to municipal elites (Friesen's 'retainers' includes probably the scribes mentioned in the New Testament). In Lenski's social stratification there is a social class called 'retainers', which consists of some $5 \%$ of the population just below the urban elite on the top of the society (Lenski 1984:243). In Friesen's stratification that would form the categories 3 and 4 .

Those who had no problems with sustenance were altogether at most $10 \%$, whereas in continuous problems of sustenance were living some $90 \%$ of the population, more than two thirds of them in severe or extreme poverty.

Naturally, poverty is a more complicated phenomenon than the mere possession of financial resources. However, in the early Roman Empire financial resources were, according to Friesen, probably the single most influential factor in determining one's place in the social economy, but not the only one. Other factors would have included gender, ethnicity, family lineage (common or noble), legal status (slave, freed, of freeborn), occupation and education. Patronage relationships were especially important in one's economic survival, for a patron gave one access to restricted resources that were otherwise unavailable (Friesen 2008:20-21).

In Ancient Mediterranean culture wealth was not, however, the most important value. Even more important, the fundamental value was honour and the public reputation of the family and its members. It has to be remembered that the culture was not individualistic; therefore the honour of the family and the kin was superior to that of an individual. Honour was achieved by being born in an honourable family or gained with some honourable deeds. It was challenged all

7.Friesen also presents interesting data on the annual income needed by a family of four, which he combines with the poverty scale above (p. 20).

8.According to E.P. Sanders, the number of the priests and Levites serving at the Jerusalem temple was 20 000, but not all were full-time (Sanders 1993:41). 
the time and could be lost quite easily. Honour was a limited good related to control of scarce resources including land, crops, livestock, political clout and female sexuality. Honour determined the position of the family in public and granted access to a better life. The counterpart of honour is shame. Being poor and especially falling to extreme poverty was never just the matter of survival of the economic crisis; much worse was the lost honour and becoming publicly despised. It was rare for the poor to be publicly respected, and very difficult to gain back honour that was once lost. ${ }^{9}$

The state did not show much concern for the poor. The city of Rome appeared to be an exception, because feeding the populace became a political necessity from the time of tribune Gaius Gracchus (154-121 BCE), ${ }^{10}$ but similar generosity shown by the officials to the poor is not recorded in ancient sources elsewhere. In the ancient world, generosity was directed rather to community, not to the needy, who were rather despised more than pitied. Liberty was highly valued: the ideal person is a free man in the sense that he is independent economically from others. 'The condition of the free man', wrote Aristotle (Rhetoric 1367:a32), 'is that he not live under the constraint of another', and it is clear from the context that his notion of living under restraint was not restricted to slaves but was extended to wage labour and to others who were economically dependent (Finley 1999:40-41). In Greek language, an independent person was called plousioi, which means 'wealthy'. Such a $\operatorname{man}^{11}$ was rich enough to live properly on his income that was derived from the property, most often from owned land that was hired to tenant farmers or worked by slaves or wage labour (Finley 1999:41). Following the stratification by Friesen, these plousioi belonged to categories 1-3 forming only a maximum $3 \%$ of the total population.

In the Roman Empire there was not an actual middle class, but between the plousioi and the destitute, ptokhoi, were peneis, the 'working class' that were not free because of their ties to toil and were compelled to devote themselves to gaining a livelihood. A penes did not necessarily lack property and was not considered poor. Such a person could even own a farm or slaves and have some monetary savings. These people belonged to Friesen's categories 4-6, thus forming approximately $70 \%$ of the population. The ptokhoi were the lowest class of people, who had no resources and whose daily life was a continuous struggle between life and death (Finley 1999:41). They were beggars, robbers, bandits, prostitutes and other despised people. The number of these destitute was, according to Friesen, remarkably high, some $28 \%$ of all.

However, ptokhoi is not used only referring to the destitute as the lowest social or economic class. In ancient Mediterranean culture it was very important to maintain one's honourable status. It was rare that somebody could get a higher status in

9.On Honor-Shame Societies cf. Malina and Rohrbaugh (2003:169-172); a more comprehensive description is offered by Malina (2001:27-57).

10.Gaius Gracchus ordered the state to buy imported grain and to store it. The grain was distributed monthly to the all Roman citizens at a low price.

11.In patriarchal society only men could be free. the society, because people tended to think that all the resources of life were limited - so it was not possible to get more wealth without deprivation from others, which was condemned as greed - and as such shameful. Normally people did not even try to get higher positions in their life and career. The landless tenant did not become a landowner; a craftsman selling his productions did not become a wealthy trader. One's status in life was thought to have been inherited by birth. It was not reasonable and honourable to try to achieve a higher status. But losing one's status was shameful. Those people, who lost their status, were also called poor, ptokhoi, independent of their earlier or comparative status in life. The status could be lost when people became incapable to pay their debts, were imprisoned, lost their inherited land or got severe illnesses, for example. Being classified as poor was the result of some unfortunate turn of events or some untoward circumstances. Consequently, the poor would not necessarily be a permanent social standing but a sort of revolving category of people who unfortunately cannot maintain their inherited status. Thus day labourers, landless peasants and beggars born into their situation were not always considered poor persons in first-century society (Malina 2001:99-100).

\section{Poverty in Galilee}

In order to understand the activity of Jesus and the early Jesus movement, it is essential to know the social and economic context where Jesus and his followers came from.

The principal literary source in first-century Galilee is Josephus, who provides a very incomplete glimpse of the political and economic character of Galilee and his account is both tendentious and self-serving. From a much later period, rabbinic literature gives a rich view of political and economic life in the Galilee, but between the first century and the time of the rabbis, the face of the Galilean society changed dramatically, because of the failure of the Second Jewish Revolt (132-135) and the large-scale displacement of Judaeans in the Galilee following it. The archaeological evidence is also quite fragmentary and still open to debate (Kloppenborg Verbin 2000:215). ${ }^{12}$

First-century Palestine was, besides being an advanced agrarian society, shaped by several dominant forces: the Israelite tradition (linguistic, cultural and religious heritage), the Roman Empire (political control) and Hellenism (the pervasive cultural influence over the whole Mediterranean and Middle East) (Hanson \& Oakman 1998:7).

Most probably the forefathers of Jesus migrated like many other Judeans from Judea to Galilee at the time of the Hasmoneans in the last third of the second century BCE, when Judea got independency after the harsh domination of the Seleucid ruler Antiochus IV Epiphanes. ${ }^{13}$ Contrary to Judea there was plenty of fertile soil available in Galilee to

12.Kloppenborg Verbin offers a good list of recent surveys of Galilee in the early Roman period.

13.A compact history of the time is offered by Raymond E. Brown (1997:56-58). 
cultivate. The area had been virtually uninhabited from the eighth to the second century BCE. ${ }^{14}$

The Hasmonean regime made it not only possible for the Judeans to immigrate to Galilee. In 104 BCE, having conquered Samaria and destroyed its temple on mount Gerizim, the Hasmoneans took over Galilee and required the local inhabitants to live according to the laws of Judea. Galilee was thus brought together with other Israelite people under the Temple and high priesthood, with the taxation system connected to the temple (Horsley 2008:25). It is not clear whether all the inhabitants of Galilee, at that time, were already originally from Judea, or if some other people were there as well. Horsley seems to count on the latter possibility, because he claims that these people now became under Judean domination for the first time. Horsley's view is based on Josephus' note that Aristobulus (104-103 BCE) 'compelled the inhabitants, if they wished to remain in the country, to be circumcised and to live in accordance with the Laws of the Judeans' (Ant. 13.318-319). However, Josephus might have been exaggerating commonalities between Judaea and Galilee for his own apologetic reasons (Kloppenborg Verbin 2000:221-223).

When the Romans occupied Palestine in 63 BCE, radical changes happened in landowning in Galilee. After the Roman civil war in $40 \mathrm{BCE}$, the whole territory was placed under the dominion of Herod, a vassal king of the Roman Emperor. Herod, later called 'the Great', had the power to distribute the land however he wanted and to whomever he wanted. He was known as a cruel ruler who did not tolerate any opposition and even had his own family members executed. Herod's kingship was approved and enlarged by Octavian in 31-30 BCE. He executed Jewish high priest Hyrcanus 2 in $30 \mathrm{BCE}$ and his own wife Mariamme 2 in $29 \mathrm{BCE}$, together with some of his own sons, whom he feared to settle against him for the kingship..$^{15}$ According to Josephus, he first 'secured' Galilee by capturing the Hasmonean garrison town Sepphoris and from there began to root out all opposition to his rule (Crossan \& Reed 2001:55).

However, his domination seems not to have brought only violence and destitution. Under his reign Judea grew economically because of his large construction projects that brought employment. His building projects included the reconstructed ancient capital of the Northern Kingdom, Samaria - now called Sebaste, the new harbour city Caesarea Maritima, the inaccessible fortress palaces at Masada and Jericho, and in Jerusalem the Fortress Antonia, a Royal Palace and a massive extension of the Temple. On the one hand, these projects increased the economic value of the whole territory to Rome, which was certainly also the purpose of Herod. On the other hand, the economic growth did not correlate to improved working and living conditions of the poor, especially not for the

14.The claim is based on the lack of archaeological evidence (Crossan \& Reed 2001:32). It was earlier presupposed that there were some Israelite population still living in Galilee when the Hasmoneans took over the dominance of the area, which would have explained the somewhat opposing attitudes of the Galileans toward example Kloppenborg Verbin, who accounts on the pre-Judean (Israelite) population in Galilee (2000:229).

15.A brief history of the time is offered by Brown (1997:58).
Galileans, because all the building projects were somewhere else. Herod himself got the biggest profit of all the growth. It must be remembered that the building projects were also aimed to Romanise the territory, because all the new cities were named to honour the Emperor and housed pagan temples to the goddess Roma and Augustus. Herod was also tolerant of the Jewish religion, which can be seen above all from his largest building project: the restoration of the temple of Jerusalem. He even lived as a Jew and defended Jewish worship outside Palestine. His tolerance was most probably a way to appease Jewish subjects, keep the peace and ensure the acceptance and compliance of the Jewish aristocracy. Maybe the reason for this was the plan of the eventual takeover of the temple and the assimilation of the Jewish people. He also remitted taxes during times of famine, because he wanted to recover their good will (Josephus, Ant. 15.10.4) - or perhaps to secure the income from Galilee also in the future (Crossan \& Reed 2001:194). ${ }^{16}$ 'Peace reigned during his rule, and the economic situation created by him was beneficial to the nation' (Räisänen 2010:23). ${ }^{17}$ That peace was, however, achieved and supported only by force and violence. The Galileans at the time of Herod the Great had a threefold taxation system: tribute to Rome, taxes to Herod and tithes and offerings to the Temple and priesthood (Horsley 2008:25; Kloppenborg Verbin 2000:224-226). ${ }^{18}$

After the death of Herod the situation in Judea and Galilee soon grew much worse. His kingdom was divided among his three sons. Archelaus became the ethnarch (ruler of the people) of Judea, Samaria and Idumea. His reign was shortlived because his rule was so autocratic and aroused the hatred of his subjects to the extent that, in $6 \mathrm{CE}$, they sent a delegation to Rome to ask for his removal. Judea became directly under Roman control. The new governor, Quirinius, the Roman legate of Syria, conducted a census for tax purposes as part of the Roman takeover (Brown 1997:60). ${ }^{19}$ The census produced a rebellion led by Judas the Galilean. The rebellion was defeated cruelly by the Romans. However, this uprising is the only one recorded in Judea at the first three decades of the Common Era. The Roman prefects of the era were Valerius Gratius and Pontius Pilate, both of whom ruled 10 years, which has often been regarded as an indication of no severe violent uprisings at the time. Also the Roman historian Tacitus (History 5.9) reports that in Judea under the

16.I am grateful for these observations to Linda Hodges. She also raised a good question, whether temple and to bring merod a dichotomy that is called 'schizophrenia of his rule' by Crossan and Reed (2001:56).

17.Räisänen's view reflects the different depictions of Galilee by scholars. Oakman (2008:246) writes: 'The very different depictions of Galilee in Sanders and Horsley offer a case in point. Sanders sees no real basis for conflict under "the good Herods," while Horsley perceives a "spiral of violence."' Since both scholars draw upon virtually the same source material, their disagreement resides largely in their conceptual frameworks. Sanders' picture of a Galilee ruled by benevolent despots with enlightened tax policies seems influenced by unwarranted political assumptions. Horsley's use of peasant studies, and sensitivity to the political realities of a colonial situation provides him with a very distinctive perspective on realities of a colonialituation provides him with a very distinctive perspective on conditions under client rulers. Cf. Horsley's (2008) view to resistance and revolt also at times of 'peace' (pp. 173-175). See also the different opinions on the
harshness of the taxation in Galilee (Oakman 2008:283-285).

18.It is not clear whether the Galileans paid also taxes to the Temple.

19.The census is referred to in Acts 5:37 and probably also in Luke 2:1-2, even though Luke seems to have placed it to another date, probably for ignorance. 
Emperor Tiberius (14-37 CE) 'things were quiet' (Brown 1997:60). However, under the Roman governors, recorded or not, there was plenty of violence in Judea and Galilee. Valerius Gratius (15-26 CE) was the first procurator who arbitrarily appointed and deposed the high priests. Josephus portrayed Gratus as manipulating Jerusalem's temple politics by deposing the incumbent Sadducean high priest Hanan 1 (6-15 CE), as well as three short-termed successors, before finally finding Joseph Kayyafa (Caiaphas), who had a long tenure collaborating with Roman military rule (18-37 CE)..$^{20}$ He put down two formidable bands of robbers that infested Judea during his government, and killed with his own hand the captain of one of them, Simon, formerly a slave of Herod the Great. ${ }^{21}$ Gratus assisted the proconsul Quintilius Varus in quelling an insurrection of the Jews. ${ }^{22}$

Pontius Pilate's first serious clash with the Jews took place in his very first year in office when his troops marched into Jerusalem at night with their regimental standards bearing medallions with the emperor's image. Jewish reaction included a large delegation to Caesarea. The very next year, $27 \mathrm{CE}$, Pilate attempted to have an aqueduct built. The point of conflict seemed to have been around the use of sacred temple money set aside for sacrificial animals for God, for the project. Indignant at this proceeding, the populace formed a ring round the tribunal of Pilate then on a visit to Jerusalem, and besieged him with angry clamour. Pilate took money from the Temple treasury to build an aqueduct for Jerusalem. His disguised troops slaughtered Jewish people in the temple courts during their protest..$^{23}$ In 29-30 CE Pilate introduced coins engraved with symbols of Emperor-worship on one side and Jewish symbols on the other. In $32 \mathrm{CE}$ he attempted - again - to bring in golden standards honouring Tiberius into Herod's Palace in Jerusalem. In 36 CE a Samaritan would-be-messiah asked the Samaritan people to go up to Mount Gerizim with him, where he promised to show them sacred vessels hidden by Moses. Pilate blocked their route of ascent with cavalry and heavily armed infantry. In the clash that followed, some were killed and the rest scattered or taken prisoners. Pilate then executed the ringleaders and those who were most influential.

Soon after Tiberius, when Emperor Caligula reigned for four years (37-41 CE), things got even worse in Judea. Caligula wanted to show his authority over Judea by attempting to have a statue divinising him erected at the Jerusalem temple. The resistance of the peasants and the untimely death of Caligula stopped the project, anyhow.

Galilee, and part of the Transjordan, was given after Herod the Great under the dominance of his son Antipas, who was named the tetrarch (ruler of a quarter-kingdom). This renewal led to many problems. It was not easy to accept the new regime, even though now the Galileans for the first time in

20.josephus, Ant. 18.2.2.

21.Josephus, Ant. 17.6.7.; Jewish War 2.4.2.3.

22.Josephus, Jewish War, 2.5.2

23.Josephus, Ant. 18.60-62; Jewish War 2.175-177. their history had their ruler living himself in Galilee. The location of the administration within a view of nearly every village meant greater efficiency in tax collection. Also, now they were no longer under Jerusalem's control (Horsley 2008:26, 46). Many riots occurred in Galilee that were forcefully vanquished. One such incidence happened at Sepphoris, a Jewish town close to Jesus' home town Nazareth, already when the news of the death of Herod the Great reached the people there. Some of the city dwellers believed that Herod's death offered them a fine possibility to found a Jewish government of their own. They rallied against foreign rule and taxation and acclaimed kingship to Judas, son of Hezekiah, but were quickly crushed by the Syrian-based Roman legate. The Romans defeated the riot with force, burned the city and sold its inhabitants to slavery. ${ }^{24}$ Sepphoris was subsequently rebuilt by Herod Antipas into Galilee's largest city and the first capital of the lands Antipas inherited from his father. Obviously members of the Herodian family belonged to the elite of the city. At the time of Jesus, Nazareth was in the shadow of Sepphoris and under Herod Antipas's political control (Crossan \& Reed 2001:33). No doubt the cruelties caused by the Romans at the era just before Jesus was born were in good memory of local peasants and had an effect on popular life in Nazareth and other Galilean and Judean villages (Horsley 2008:40).

As typical for agrarian societies, Galilee was dominated by only a few major families, including most probably the families of Caesar, Pilate and other prefects, Herods and especially Antipas's court officials, high priests and possibly some successful merchants and a few overseers of the collection of taxes and tolls. When peasant families grew larger it was no more possible to cultivate new land for new generations as it was earlier done.

In biblical scholarship, it was earlier presumed that Galilee would have had important trading routes for international use because of its location, and that the Galileans themselves would have traded their products to big cities around the eastern part of the empire. This view was based on lively counteractions between Galilean cities and villages, for example, it was argued that Galilean villagers used to sell their products at the markets in Sepphoris and Tiberias. Concluding from some remains of coinage the Galileans were supposed to have had even remarkable trading with olive oil to Syria, especially to its big trading city Tyros. Richard Horsley has, however, questioned the view of Galilee as a relatively lively trading area. Ancient Tyrian coins found from Galilee show most of all what kind of money was normally used in Galilee, and as such it is no evidence from any trade at the area, because the same coinage was used widely in the eastern part of the empire. The other archaeological remains from first-century Galilee refer rather to a remote region, with little influence from Greek-speaking Tyros. For example, the pottery remains show that the pottery distribution was not wide outside Galilee (Horsley 1996:83-85).

24.Josephus, Jewish War 268 -69; Jewish Antiquities $17288-289$. Josephus might however, exaggerate the devastation, since no archaeological evidence is found from the site that fits to the destruction of the whole city. His description of Antipas's from the site that fits to the destruction of the whole city. His description of Antipas's
rebuilding Sepphoris into the 'ornament of Galilee' (Jewish Ant. 18.27) resonates rebuilding Sepphoris into the 'ornament of Galilee' (Jewish Ant. 18.
though with the archaeological record (Crossan \& Reed 2001:65-66). 
Herod Antipas, needing to expand his revenues in order to fund his ambitious city-building, developed fishing into an industry. Working through brokers as intermediaries, the king supplied the equipment, especially the costly large (26-foot) boats that required a crew of five or six. ${ }^{25}$ Collaborative crews evidently contracted to deliver a certain percentage or amount of their catch to the processing depots in return for keeping the rest (somewhat like sharecroppers). The principal processing centre for the fish was Magdala ('tower of fish' in Aramaic), where people cut loose from their ancestral lands and village communities found work (Hanson \& Oakman 1998:106-110; Horsley 2008:48). Recent excavations in Magdala have revealed Roman-type city architecture, but the results of the excavations have not yet been published, so the dating of the Roman type of buildings is still open.

Antipas wanted to honour the Emperor by building two Roman cities in Galilee. These cities, that were under the construction process when Jesus was a young man, were Sepphoris and Tiberias, which became the only cities in Galilee with all the pagan buildings like temples and theatres (if the Romanised Magdala is not from the same time period). Sepphoris was rebuilt after the destruction by the Romans, now in a more Roman style as a new capital of Galilee. At the time of Antipas, Sepphoris was, however, not yet totally pagan, which might tell of the carefulness of Antipas not to irrigate the Jewish population at the area - like his father he wanted respect also from the Jews (Crossan \& Reed 2001:64; Kloppenborg Verbin 2000:242-245; Reed 1994:203-219). ${ }^{26}$ Tiberias was built some 20 years after Sepphoris on the former Jewish cemetery as the new capital of Antipas and named for the emperor Tiberius. As Horsley writes:

Both cities, built in Roman style by a king who had been educated in Rome, must have seemed like alien urban culture set down into the previously Israelite rural landscape remote from the dominant high culture. (Horsley 2008:46)

The construction projects brought employment for many landless people, but at the same time aroused critics because they were regarded as Antipas's tendency to Romanise Galilee and at least partly funded by taxation. As peasant families could not meet the demands of taxes or became indebted by buying the necessities they used to grow, possession of their land was transferred elsewhere. Estates grew and tenancy increased. Architectural grandeur increased at one end of Galilean society by making poverty increase at the other (Crossan \& Reed 2001:70; Freyne 1995:23-46). Both cities were the centres of taxation with collection and storage points for tax revenues and they housed the debt archives. The wealthy inhabitants of the cities differed significantly from those living in villages. This was the substratum for several movements opposing Rome

25.This kind of a fishing boat was found from the mud near ancient Magdala in 1986 and is now seen at Yigal Allon Museum, Kibbutz Ginnosar (cf. Crossan \& Reed (2001:85-87). However, this particular boat seems to have been built of used material and repaired several times until it was finally totally rejected, which led Crossan and Reed argue: 'Herod Antipas's commercial kingdom didn't launch a fishing or mercantile fleet on the lake' (p. 87).

26. Reed estimates that Sepphoris had the population of approximately 24000 inhabitants (Reed 1994:203-219). There is no evidence of priests belonging to the elite of either of the Galilean cities in the First Century, even though after the First Revolt (66-70 CE) and especially after the Second Jewish Revolt (135 CE) the cities became centers of former priests and Jewish education (Kloppenborg Verbin became centers
2000:242-245).
(Freyne 1988:166; Kloppenborg Verbin 2000:235, 237, 246247; Meier 1991:282-283; Oakman 2008:21, 168-171). ${ }^{27}$ One of these, and the most influential as it appeared to be, was the Jesus movement. It seems to have attracted especially, like some other anti-Roman movements, the landless: peasant children without inheritance, expropriated smallholders and all kinds of people who were deprived of access to the land. The changed situation from a landowner, a peasant farmer, into a tenant farmer or day labourer was dramatic for many Galileans. The peasant farmers were permanently poor and in continuous danger to fall under the subsistence level.

One bad harvest or one serious misfortune might mean the loss of everything, since the new patronal class, already viewed with distrust, could not be depended upon for help. (Kloppenborg Verbin 2000:261)

If they lost the essential resources of living, they became destitute. That caused banditry, itinerancy, slavery, prostitution and robbery. Especially Richard Horsley has pointed out that 'social banditry' was typical for Galilee. It was a prepolitical and non-organised form of protest against injustice and resistance to occupation and its deleterious effects. Supposedly many of the bandits were dispossessed peasants, who were supported by the peasantry in Galilean villages (Horsley 1987:38).

Crossan and Reed argue that the reason for Jesus' itinerant lifestyle might not have been a voluntary abandonment of normal family life or some ideological reasons or of some crisis in the family relations, but simply a loss of everything because of the harsh taxation, strong indebtedness and bad crop. Only later it became idealistic asceticism (Crossan \& Reed 2001:127-128). A distinguishing view is offered by Horsley, who thinks it was just the strongly indebted peasant farmers in danger of losing their ancestral land who formed the Jesus movements. Horsley's description of peasant life in Galilean villages is also quite convincing, but from it one gets the impression that itinerancy was a choice of some followers of Jesus to spread the movement from village to village, not necessarily caused by extreme poverty and loss of land and permanent household (Horsley 2008:46-55).

So, first-century Galilee was mainly agricultural, with little fishing industry, and its population was economically strongly dependent on the wealthy elite, the majority of whom lived in Sepphoris and Tiberias, some even in Jerusalem. The elite lived by depriving the Galilean rural population, with no direct connection to the ordinary people. Their agents collected taxes, and usually the villagers had the opportunity to deal with minor legal things themselves in local assemblies, the synagogues. The poverty in Galilee is also reflected by the fact that almost no remains of storage buildings for grain or other products have been found in archaeological excavations in Galilee and no shops at all. The Galileans seem to have consumed all they produced. Having paid the rents, taxes, loan remissions and interests there simply was nothing left to trade with.

27. Contrary to this is John P. Meier's note: 'Indeed for all the inequities of life, the reign of Herod Antipas (4 B.C. - 39 A.D.) in Galilee was relatively prosperous and peaceful, free of the severe social strife that preceded and followed it ... Milder than his father Herod the Great, he was an able ruler who managed to live at peace with his people. It was no accident that he ruled longer than any other Herodian with his people. It was no accident that he ruled
king or prince, with the exception of Agrippa II'. 
Literacy was even more limited in Judea and Galilee than in the rest of the Roman Empire. Writing was confined mainly to scribal circles and high priestly administrations. Oral communication dominated at all levels of the society, completely so in the villages (Horsley 2008:29). Horsley notes that

[t]his makes the old depiction of the ancient Jews as generally literate and a 'people of the book' highly dubious. So, too, it also calls into question the frequent assumption that early Christians were also literate and quickly also became a 'people of the book.' This means, for example, that Judean texts from around the time of Jesus do not provide evidence for what the Jews in general believed and practiced, but only for the literate circles that produced those texts. (Horsley 2008:29)

Even if the Galilean villagers would have had possession of some scrolls, which they most probably did not, they would not have understood it read to them, because they spoke a dialect of Aramaic that deviated from the Hebrew of the sacred texts. They would have known the existence of the sacred scriptures, because it was deposited in the Temple and supposedly to be read or rather recited on ceremonial occasions. Some fragmentary knowledge of the scripture may also have been mediated to villagers through Pharisees and other scribal representatives of the temple-state. Having some knowledge of the scriptures and even the ability to recite them did not, however, mean literacy in the sense of ability to read (Horsley 2008:29, 89-92). Most probably, Jesus could not read or write (Oakman 2008:171). ${ }^{28}$

The social stage of Jesus and his family is not easy to determine. All the archaeological evidence from the Roman period points to a simple peasant existence at Nazareth. It also points to a Jewish Nazareth. The size of the village was small. It could have been inhabited by about $200-400$ people, which means several extended families or clans (Crossan \& Reed 2001:34-35). ${ }^{29}$

Many scholars are of the opinion that the poor in Galilee were small farmers with inadequate or barren land, or serfs on large estates. Under heavy taxation and debts they lived continuously at subsistence level or below it. Typical to Mediterranean peasantry, they most probably practiced viticulture, arboriculture and agriculture and had a vegetable diet, supplemented by yoghurt and cheese, and in rare occasions with poultry, lamb or beef. Productivity was relatively low. Excess peasant labour may be devoted to craft specialisation if agricultural opportunities dwindle and tax pressures are high (Oakman 2008:167). ${ }^{30}$

Many peasants had lost their ancestral land. Also surplus children of peasant households were often forced to leave the

\section{This is implied also by Horsley (2008:89-92).}

29.I find Crossan's and Reed's estimation of the population more trustworthy than Meier (1991:280), who writes: '[Jesus] lived in a village of between roughly 1600 and 2000 people'. Meier does not say on what premises he bases his 1600 and 2000 people. Meier does not say on what premises he bases his archaeological evidence.

30.Oakman gives a fine description of the reasons leading to and the process of the change from a landowner to a landless peasant (pp. 168-169). village in search of livelihood (Lenski 1984:278). In Friesen's categories the majority of the farmers would have belonged to groups 6 and 7. It seems to me that in the first-century-Galilee many families moved from group 6 to group 7 and even to slavery.

When it comes to Jesus, in the Gospel of Mark (6:3) there is a brief mention of his trade: he was a tekton. ${ }^{31}$ This Greek word is traditionally translated as 'carpenter', which is probably because of middle-age paintings. Indeed, tekton basically means a builder of any kind. So, Jesus was not necessarily a carpenter or a 'wood-worker, who made doors or furniture for the stone or mud-brick houses and ploughs and yokes for farmers' (Brown 1997:67). A tekton could have referred as well to a sculptor or - most probably in this case - to a craftsman who works at the buildings made of stone (Batey 1984:249258). ${ }^{32}$ It has to be remembered that there were large building projects in Galilee at the time of Jesus, and an especially important one just a few miles (one hour's walk) from Nazareth, his childhood home town. When the Romans built Sepphoris they certainly used local people, both slaves and waged labourers from nearby villages. If Jesus' family had the same difficulties that almost every family at that time had, they could not afford a large family and some members of the family had to leave farming and find a job elsewhere (Oakman 2008:171). ${ }^{33}$ It might as well be that the tekton in Mark 6:3 refers to a stoneworker, city builder, in which case the word gives a slightly negative impression - as it is indeed clear from the context: the people in Nazareth do not accept Jesus, who is a 'tekton', but implies to have more wisdom than the others. It looks like Jesus was despised because he had worked in the Roman building project, constructing a pagan city of Sepphoris. If this were the case, Jesus might not be compared to 'a blue collar worker in lower-middle-class America' (Meier 1991:276-285). ${ }^{34}$ Rather, he would have belonged to Friesen's group 6 or 7 (at subsistence level or below it), depending on his skill, as a landless peasant who worked some time as a labourer in the nearby city. ${ }^{35}$ The movement led by him promised subsistence in the Kingdom of God (Mk 10:30; Lk 12:22-31/Mt 6:25-33). He spoke about debts, and taught his disciples to pray for the forgiving of

31. Matthew, most probably out of respect, changes the Markan text so that in his story of the same event, that is evidently dependent on Mark's story, Jesus is the son of the tekton, Matth. 13:55. Luke, likewise depending on Mark's text, omits the trade entirely, Luke 4:22

32.The term tekton could be applied to any worker who plied his trade with a hard material that retains its hardness throughout the operation, for example, wood and stone or even horn or ivory.

33.I agree with Oakman, who writes: 'Occupationally, Jesus is best understood as a peasant child forced to leave the village in search of livelihood (Mk 6:3)'.

34.Meier regards Jesus as coming from a peasant background, 'but he is not an ordinary peasant.' The peasant background explains why a good deal of the imagery in Jesus' parables and metaphorical language is taken from agriculture. However, even though Meier regards Jesus as a wood-worker, he considers it possible (but not probable) that Jesus worked in Sepphoris for a while (p. 284). M.I. Finley(1999:185-186) describes the Roman custom of building projects in urban environments: 'No doubt many skilled artisans picked up casual work on public projects when the opportunity arose (and when they needed it, which must have been often)'. He then gives an example from Delos, 'where the detailed financial records reveal the frequency with which a

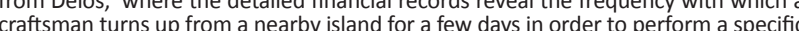
craftsman turns up from a nearby island for a few days in order to perform a specific piece of work, not to reappear for months or years or even ever again. In the biggest cities, 'tens of thousands of unskilled and semi-skilled men must have found frequent, though strictly speaking casual, employment in that major urban activity of
all pre-industrial societies, the building trade'.

35.Meier (1991:313, n. 168 and 169) disclaims some arguments by scholars, who argued that Jesus and his father were relatively well to do. 
debts (Mt 6:12; Lk 7:41-42; Lk 11:4). At least from the beginning, the Jesus movement seemed to be 'a movement of the poor for the poor' (Stegemann 1984:23).

The third part of Herod the Great's kingdom, the areas north and east of the Lake of Galilee, including Decapolis, was given to Herod's son Philip. The kingdom of Herod was re-established by Emperor Claudius (41-54 CE), who gave the areas ruled by Herod's sons to Herod's grandson and the emperor's good friend Agrippa. The new governor first appeared tolerant to Jewish inhabitants of the territory, but his rule was to become fatal for the Jesus-believing Jews in Jerusalem: according to Acts 12 he was responsible for the persecution that killed James the brother of John, son of Zebedee. After Agrippa's death the rule of Palestine was again given under direct Roman rule. The procurators of the period 44-66 CE were, however, 'of low calibre, vicious and dishonest, provoking intense unrest by their injustice' (Brown 1997:61). Their misrule gave rise to Sicarii (knife-wielding terrorists, who attacked especially pro-Roman Jewish elites), Zealots (ruthless adherents of the Law), and a major Jewish revolt against the Romans (the Jewish war in 66-70 CE). The Roman legions led by Vespasian marched from Syria to Judea to quell the revolt. When Vespasian became an Emperor after Nero, his son Titus conquered Jerusalem, destroyed the temple and burned the city. Most of the surviving Jews, including the Jesus-believers who did not take part of the armed revolt, had to leave the city (Brown 1997:61). ${ }^{36}$

The defeat in the Jewish war and the religious crisis followed by the destruction of the temple made life for Jews everywhere in the Empire difficult. They were now publicly shamed. The war inevitably increased poverty in Palestine. The Jews were obliged to pay a new punitive tax of two drachmas for the support of the temple of Jupiter Capitolinus in Rome.

\section{Acknowledgements Competing interests}

The author declares that he has no financial or personal relationships which may have inappropriately influenced him in writing this article.

36.Probably the Jesus-believing community moved from Jerusalem across the river Jordan to Pella.

\section{References}

Batey, R.A., 1984, 'Is not this the carpenter?', New Testament Studies 30, 249-258.

Brown, R.E., 1997, An introduction to the New Testament (The Anchor Bible reference library), Doubleday, New York.

Crossan, J.D. \& Reed, J.L., 2001, Excavating Jesus: Beneath the stones, behind the texts, Harper, San Francisco, CA.

Finley, M.I., 1999, Ancient economy, 2nd edn., updated Edition with a foreword by I. Morris, Sather Classical Lectures 43, University of California Press, London.

Freyne, S., 1988, Galilee, Jesus and the gospels: Literary approaches and historical investigations, Fortress Press, Philadelphia, PA.

Freyne, S., 1995, 'Herodian economics in Galilee', in P.F. Esler (ed.), Modelling early Christianity: Social-scientific studies of the New Testament in its context, pp. 23-46, Routledge, London.

Friesen, S.J., 2008, 'Injustice or God's will? Early Christian explanations of poverty', in S. Holman (ed.). Wealth and poverty in early church and society. Holy cross studies in patristic theology and history, Baker Academic, Grand Rapids, MI.

Garnsey, P. \& Saller, R., 1987, The Roman Empire economy, society, and culture, University of California Press, Berkeley, CA.

Gottwald, N.K., 2008, 'Early Israel as an anti-imperial community', in R. Horsley (ed.), In the shadow of empire: Reclaiming the Bible as a history of faithful resistance, pp. 9-24, Westminster John Knox Press, London.

Hanson, K.C. \& Oakman, D., 1998, Palestine in the time of Jesus: Social structure and social conflicts, 2 nd edn., Fortress Press, Minneapolis, MN.

Horsley, R.A., 1987, Jesus and the spiral of violence: Popular Jewish resistance in Roman Palestine, Harper \& Row, San Francisco, CA.

Horsley, R.A., 1996, Archaeology, history, and society in Galilee. The social context of Jesus and the rabbis, Trinity Press, Valley Forge, PA.

Horsley, R.A., 2008, Jesus in context: Power, people \& performance, Fortress Press, Minneapolis, MN.

Kloppenborg Verbin, J.S., 2000, Excavating Q. The history and setting of the sayings gospel, Fortress Press, Minneapolis, MN.

Lenski, G.E., 1984, Power and privilege: A theory of social stratification, The University of North Carolina Press, North Carolina.

Malina, B.J., 2001, The New Testament World: Insights from cultural anthropology, 3rd edn., revised and expanded, Westminster John Knox Press, Louisville, KY.

Malina, B.J. \& Rohrbaugh, R.L., 2003, Social-science commentary on the synoptic gospels, 2nd edn., Fortress Press, Minneapolis, MN

Meier, J.P., 1991, A marginal Jew. Rethinking the historical Jesus. Volume one: The roots of the problem and the person, The Anchor Bible Reference Library, Doubleday, New York.

Oakman, D.E., 2008, Jesus and the peasants, matrix: The Bible in Mediterranean context, Cascade Books, Eugene, OR.

Reed, J.L., 1994, 'Populations numbers, urbanization, and economics: Galilean archaeology and the historical Jesus', in E.H. Lovering (ed.), Society of biblical literature 1994 seminar papers, pp. 203-219, Scholars Press, Atlanta, GA.

Räisänen, H., 2010, The rise of Christian beliefs. The thought world of early Christianity, Fortress, Minneapolis, MN.

Rohrbaugh, R.L., Palestine in the time of Jesus, review of Hanson \& Oakman, Interpretation.

Rohrbaugh, R.L., 1993, 'The social location of the Markan audience', Interpretation 47, 380-395.

Sanders, E.P., 1985, Jesus and Judaism, SCM Press, London.

Sanders, E.P., 1993, The historical figure of Jesus, Penguin Books, London.

Stegemann, E.W. \& Stegemann, W., 1999, The Jesus movement: A social history of its first century, transl. O.C. Dean Jr., Fortress Press, Minneapolis, MN.

Stegemann, W., 1984, The gospel and the poor, transl. D. Elliott, Fortress Press, Philadelphia, PA. 